\title{
PENINGKATAN HASIL BELAJAR MELALUI MEDIA KOLASE PADA PEMBELAJARAN TEMATIK KELAS IV SEKOLAH DASAR
}

\author{
Puji Astuti \\ e-mail: astuti_fuji22@yahoo.com \\ Sekolah Tinggi Ilmu Kesehatan (STIK) Bina Husada Palembang
}

Jalan Syech Abdul Somad No. 28 Kel. 22 Ilir Palembang, Sumatera Selatan

\begin{abstract}
Abstrak: Berbagai macam media pembelajaran berfungsi untuk menunjang kegiatan pembelajaran dalam upaya mencapai hasil belajar, termasuk penggunaan media kolase. Tujuan penelitian ini adalah untuk meningkatnya hasil belajar pada siswa kelas IV SD pada pembelajaran tematik dengan menggunakan media kolase. Penelitian ini adalah penelitian tindakan kelas yang dilaksanakan di SDN 02 Margo Mulyo OKU Timur yang dilaksanakan selama 3 bulan pada tahun 2020. Prosedur penelitian yang digunakan adalah model John Elliot yang mencakup tahapan perencanaan, tindakan, observasi, dan refleksi. Hasil penelitian melaporkan bahwa terdapat peningkatan nilai rata-rata siswa dari pra siklus 74,89 meningkat menjadi 76,30 pada siklus pertama, dan meningkat menjadi 79,00 pada siklus kedua. Persentase ketuntasan belajar dilaporkan meningkat pada setiap siklusnya, dari $52 \%$ pada pra siklus, menjadi $68 \%$ pada siklus pertama, dan menjadi $90 \%$ pada siklus kedua. Secara klasikal telah tercapai indikator yang ditetapkan yaitu persentase ketuntasan belajar siswa mencapai $\geq 75 \%$ siswa dengan nilai $\geq 75$. Aktivitas belajar siswa dan mengajar guru selama proses pembelajaran menggunakan media kolase berkategori sangat baik. Saran penelitian adalah perlu dilakukannya kegiatan pendampingan pada guru dalam memilih, menggunakan, dan memanfaatkan media pembelajaran.
\end{abstract}

Kata-kata Kunci: hasil belajar, media kolase, pembelajaran tematik

\section{THE IMPROVEMENT OF FOURTH GRADE PRIMARY SCHOOL STUDENTS' THEMATIC LEARNING OUTCOMES THROUGH COLLAGE MEDIA}

\begin{abstract}
There are various media to support learning and improve learning outcomes, including collage media. This research aims to describe the outcomes of fourth-grade primary school students' thematic learning using collage media. This research is a classroom action research that was conducted for 3 months in 2020 at SDN 02 Margo Mulyo OKU Timur. The research procedure used is the John Elliot model which includes the stages of planning, observation, and reflection. The results reported the increase of students' mean score from the pre-cycle 74,89 to 76,30 in the first cycle and increased to 79,00 in the second cycle. The percentage of learning completion reported to have increased in each cycle, from $52 \%$ in the pre-cycle, to $68 \%$ in the first cycle, and $90 \%$ in the second cycle. Classically, the proposed indicators have been achieved with student learning completion reaching $\geq 75 \%$ with $\geq a$ 75 score. Teacher and student learning activities with collage media are categorized very well. The research suggests that teachers must study the selecting, using, and utilizing learning media process.
\end{abstract}

Keywords: learning outcomes, collage media, thematic learning 


\section{PENDAHULUAN}

Seiring berkembangnya zaman yang didukung dengan hadirnya teknologi dan informasi, yang berdampak perubahan di dunia. Telah banyak ditemukan media pembelajaran guna menunjang kegiatan pembelajaran, sehingga hal ini berpengaruh dalam metode yang digunakan para pengajar. Berbagai macam media pembelajaran tersebut berfungsi untuk menarik minat siswa, agar dapat mengikuti proses belajar dengan baik. Briggs dalam Sudrajat (2008) menyatakan bahwa media pembelajaran merupakan salah satu cara atau alat bantu yang digunakan dalam proses belajar mengajar. Media pembelajaran adalah sarana fisik untuk menyampaikan isi atau materi pembelajaran seperti: buku, film, video dan sebagainya.

Hal ini dilakukan untuk merangsang pola pembelajaran, agar dapat menunjang keberhasilan dari proses belajar, sehingga kegiatan pembelajaran dapat efektif untuk mencapai tujuan pembelajaran yang diinginkan. Akan tetapi, banyaknya media pembelajaran tersebut belum dimanfaatkan secara maksimal oleh sebagian guru, seperti yang dinyatakan oleh Yusrizal, dkk. (2017). Hal ini bisa disebabkan oleh berbagai macam hal, salah satunya yaitu kurangnya pengetahuan atau bahkan kemauan dari para guru itu sendiri untuk memanfaatkan berbagai media pembelajaran tersebut. Kini berbagai penelitian di kajian media telah banyak menguji dan menjelaskan pemanfaatan berbagai media pembelajaran yang efektif untuk mencapai keberhasilan dalam proses belajar mengajar, seperti yang dilakukan oleh Wicaksono \& Duta (2020) yang meneliti pemanfaatan TIK pada pelajaran pendidikan jasmani. Juga yang dilakukan pada pemanfaatan media berbasis TIK oleh guru SD dalam penelitian Sinaga (2020).

Keberhasilan kegiatan pembelajaran sangat dipengaruhi oleh guru itu sendiri sebagai pengelola utama di dalam kelas. Kemampuan guru di dalam mengatur serta mengorganisir lingkungan yang ada di sekitar peserta didik dapat mendorong peserta didik melakukan proses belajar secara efektif dan efisien. Di samping itu guru juga dituntut harus mampu menjabarkan kompetensi yang diampunya ke dalam kegiatan pembelajaran yang dapat mendorong peserta didik terlihat aktif selama pembelajaran. Terkadang siswa kurang tertarik atau antusias terhadap suatu pelajaran dikarenakan materi pelajaran yang sulit, susah dicerna, hal-hal berkonsep abstrak yang sulit bila dijelaskan secara lisan misalnya bagian-bagian tubuh mahluk hidup.

Kenyataan ini tentunya dapat menjadi inspirasi untuk menyajikan sebuah media pembelajaran yang dapat membuat siswa belajar secara aktif dan menyenangkan. Media pembelajaran tersebut dapat dirancang sesuai dengan tingkat perkembangan siswa SD dan perkembangan teknologi yang ada di masyarakat. Media yang dirancang tersebut bisa berisi materi yang ada pada tema dan subtema yang akan dipelajari secara terintegrasi. Dengan menghadirkan media pembelajaran diharapkan suasana kelas akan lebih fresh dan siswa dapat lebih berkonsentrasi, terlebih ketika media pembelajaran yang digunakan bersifat unik dan menarik. Siswa akan lebih jelas memahami apa yang dijelaskan oleh guru di kelas. Dengan media pembelajaran, proses belajar mengajar di kelas diharapkan sukses sesuai dengan tujuantujuan yang ingin dicapai oleh guru di kelas yang nantinya akan dapat meningkatkan hasil belajar siswa.

Sejumlah penelitian yang pernah dilakukan terkait pemanfaatan media pada pembelajaran tematik telah dilakukan oleh Veronica, dkk. (2019) yang melakukan pengembangan media scrapbook untuk siswa kelas 1 SD. Juga Sunarti dkk (2016) yang mengembangkan game petualangan untuk pembelajaran tematik di kelas IV SD. Saputro \& Soeharto (2015) melakukan pengembangan komik untuk pendidikan karakter di SD. Jadi berbagai jenis media pembelajaran dapat dikembangkan untuk digunakan dalam pembelajaran tematik.

Berdasarkan observasi yang peneliti lakukan pada Bulan Oktober 2020 juga melalui informasi dan penjelasan dari guru kelas IV SD Negeri 02 Margo Mulyo OKU Timur menyatakan bahwa pembelajaran tematik yang diterapkan sesuai Kurikulum 2013, perlu menggunakan media dalam proses pembelajaran. Apalagi pada masa pandemi COVID-19, guna menyampaikan materi-materi yang sulit dipahami siswa terlebih lagi yang bersifat abstrak. Informasi lain juga menginformasikan bahwa terjadi penurunan nilai siswa pada pembelajaran terkhusus Seni Budaya dan Prakarya (SBdP) yang berdampak pada tidak tercapainya ketuntasan hasil belajar siswa secara klasikal. Begitu juga pada pembelajaran Pendidikan Pancasila dan Kewarganegaraan (PPKn). Hal ini disebabkan karena pembelajaran masih bersifat konvensional dan dengan penyampaian materi dengan ceramah, guru tidak menggunakan alat bantu pembelajaran, sehingga siswa hanya menjadi pendengar yang baik dan pasif. Persentase ketuntasan belajar siswa masih di bawah kriteria ketuntasan minimum yaitu 75. Guna memfasilitasi belajar tersebut, 
perlu perbaikan pembelajaran dengan memanfaatkan dan menggunakan media pembelajaran pada proses pembelajaran di sekolah tersebut.

Berdasarkan hasil observasi, peneliti perlu berkolaborasi dengan guru kelas dalam melakukan perbaikan pembelajaran berupa penelitian tindakan kelas dengan memanfaatkan media yang ada di lingkungan sekolah dan siswa. Media yang tepat yang dapat digunakan untuk meningkatkan hasil belajar siswa fokus pembelajaran PPKn dan SBdP dengan menggunakan media kolase. Penggunaan media kolase dapat membuat siswa lebih kreatif, lebih aktif dan membuat siswa tidak merasa bosan pada saat berlangsungnya proses pembelajaran.

Hasuki (2010) mengartikan kolase sebagai permainan keterampilan melengkapi gambar menggunakan bahan tertentu. Anak diminta menempelkannya pada bidang yang tepat seperti yang diperintahkan atau dimanapun ia menyukainya. Bahkan terkadang kolase mengharuskan anak untuk menggunting atau merobek bahan yang digunakan sesuai dengan kebutuhan. Kolase selain menarik dan menyenangkan, juga memiliki manfaat yang besar bagi anak.

Pemanfaatan kolase pada pembelajaran sudah dilakukan oleh beberapa peneliti sebelumnya. Lubis (2020) meneliti bagaimana media kolase berbasis gambar digunakan untuk pembelajaran tema keberagaman suku bangsa di Madrasah Ibtidaiyah. Shalahudin (2019), melakukan penelitian Tindakan dengan menggunakan media kolase yang berbasis pemanfaatan daur ulang sampah dapat meningkatkan kreativitas siswa madrasah.

Tujuan penelitian ini adalah untuk memfasilitasi belajar dan meningkatkan hasil belajar siswa kelas IVSD pada pembelajaran tematik menggunakan media kolase. Kontribusi penelitian ini bagi guru adalah upaya meningkatkan hasil belajar siswa serta kesiapan guru dalam memanfaatkan media pembelajaran. Sedangkan bagi institusi pendidikan sebagai alternatif dalam rangka meningkatkan mutu dan kompetensi guru serta hasil belajar siswa.

\section{METODE PENELITIAN}

Penelitian ini adalah penelitian tindakan kelas (Classroom Action Research) yang dilaksanakan dengan mengikuti prosedur penelitian model John Elliot yang mencakup kegiatan perencanaan (planning), tindakan (action), observasi (observation), dan refleksi (reflection). Penelitian tindakan kelas ini menggunakan jenis partisipan yang artinya penelitian yang mengharuskan peneliti untuk berpartisipasi secara langsung sejak awal hingga akhir penelitian, dari proses perencanaan hingga selesainya penelitian. Alur penelitian tindakan kelas seperti pada gambar sebagai berikut:

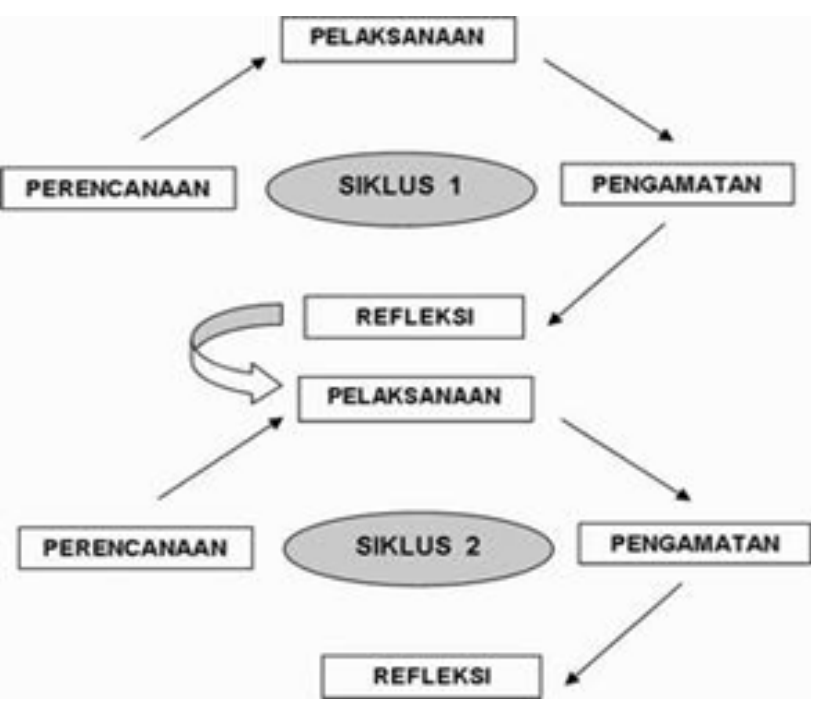

Gambar. 1 Alur PTK model John Elliot

Tahapan ini berlangsung secara berulang dalam bentuk siklus, sebagai berikut: (1) Tahap perencanaan (planning). Tahapan ini peneliti menyusun dan merancang tindakan yang akan dilaksanakan untuk meningkatkan hasil belajar siswa. Rencana tindakan yang dilaksanakan pada tahapan ini adalah rancangan pembelajaran yang dikembangkan berdasarkan masalah yang ditemukan dan menyiapkan media pembelajaran yang dipakai media kolase untuk memecahkan masalah rendahnya hasil belajar siswa. (2) Tahap pelaksanaan (action). Pada langkah ini peneliti melakukan langkah-langkah pembelajaran dengan mebggunakan media kolase sesuai dengan rancangan pembelajaran yang telah dipersiapkan pada langkah pertama. (3) Tahap pengamatan (observation). Pengamatan dilakukan pada waktu pembelajaran sedang berlangsung. Peneliti bersama dengan teman sejawat, yaitu guru kelas IV, mencatat semua hal yang ditemukan dan diperlukan saat pengamatan. Berikut hal-hal yang diamati pada aktivitas siswa dan guru sepanjang penelitian.

Tabel 1.

Lembar Pengamatan Siswa

\begin{tabular}{cl}
\hline No & \multicolumn{1}{c}{ Hal-hal yang diamati } \\
\hline 1 & Memperhatikan instruksi/penjelasan guru \\
2 & Antusia selama proses pembelajaran \\
3 & Memberikan tanggapan / respon \\
4 & Aktif menggunakan media kolase \\
\hline
\end{tabular}

PERSPEKTIF Ilmu Pendidikan - Vol. 35 No. 1 April 2021 
Tabel 2.

Lembar Pengamatan Guru

\begin{tabular}{cl}
\hline No & \multicolumn{1}{c}{ Hal-hal yang diamati } \\
\hline 1 & Apersepsi \\
2 & Menyampaikan tujuan pembelajaran \\
3 & Menyampaikan materi pembelajaran \\
4 & Menjelaskan langkah-langkah menggunakan \\
& media kolase \\
5 & Membimbing/mengarahkan kerja siswa \\
6 & Mempresentasikan hasil kerja siswa \\
7 & Melakukan kesimpulan pembelajaran \\
\hline
\end{tabular}

(4) Tahap refleksi. Pada tahap refleksi, data yang diperoleh dari hasil evaluasi kemudian dilakukan analisis. Hasil analisis digunakan untuk merefleksi pelaksanaan tindakan pada siklus tersebut, hasil refleksi kemudian digunakan untuk merencanakan tindakan pada siklus berikutnya. Kegiatan refleksi ini dilaksanakan secara kolaborasi antara guru dan peneliti. Dalam hal ini, melakukan refleksi tentang hasil observasi yaitu pada saat pembelajaran berlangsung, hasil tes penilaian/ evaluasi pada tiap akhir siklus. Tahapan ini dimaksudkan untuk mengkaji secara menyeluruh tindakan yang telah dilakukan, berdasarkan data yang telah terkumpul.

Penelitian ini dilaksanakan di SD Negeri 02 Margo Mulyo OKU Timur pada Bulan OktoberDesember 2020. Partisipan penelitian adalah seluruh siswa kelas IV, yang berjumlah 31 orang. Peneliti berkolaborasi dengan guru kelas sebagai teman sejawat. Penelitian ini dilaksanakan pada masa pandemi Covid-19, di mana sekolah ini melakukan pembelajaran dengan strategi 3 (tiga) hari belajar di sekolah dan 3 (tiga) hari belajar dari rumah. Peneliti melaksanakan penelitian ini dengan persetujuan pihak sekolah dan dengan mematuhi protokol kesehatan pencegahan Covid-19.

Teknik pengumpulan data yang digunakan dalam penelitian ini, adalah dengan melakukan observasi, yang menggunakan lembar pengamatan untuk mengetahui keaktifan siswa selama pembelajaran berlangsung. Instrumem yang digunakan berupa lembar observasi yang akan digunakan selama proses pembelajaran. Sedangkan untuk mengetahui hasil belajar, maka diberikan tes pada siswa setiap akhir siklus.

Data yang diperoleh dalam setiap tindakan selanjutnya dianalisis menggunakan analisis deskriptif dengan menghitung nilai rata-rata hasil belajar siswa dan persentase ketuntasan hasil belajar dari prasiklus dan persiklusnya. Menggunakan rumus: a. Hasil tes belajar siswa Mencari nilai rata-rata kelas :

$$
M=\frac{\sum f x}{N}
$$

Keterangan:

$\mathrm{M}$ = rata-rata

$\sum \mathrm{fx}=$ jumlah semua nilai siswa

$\mathrm{N}$ = banyaknya siswa (Indarti, 2008)

Mencari persentase ketuntasan hasil belajar siswa

$P=\frac{F}{N} X 100 \%$

Keterangan:

$\mathrm{P}=$ persentase hasil belajar

$\mathrm{F}=$ total nilai hasil belajar

$\mathrm{N}=$ jumlah siswa (Indarti, 2008)

Tingkat pemahaman siswa ditentukan dengan menggunakan kriteria penilaian (Arikunto, 2010) sebagai berikut:

$76 \%-100 \%=$ Baik sekali

$51 \%-75 \%=$ Baik

$26 \%-50 \%=$ Cukup

$<26 \%=$ Kurang

b. Hasil pengamatan siswa dan guru

$P=\frac{F}{N} X 100 \%$

Keterangan:

$\mathrm{P}=$ Presentase aktivitas

$\mathrm{F}=$ Banyak aktivitas guru/siswa yang muncul

$\mathrm{N}=$ Jumlah aktivitas keseluruhan (Indarti, 2008)

Untuk memberikan makna terhadap angka persentase, maka digunakan ketetapan dengan kriteria penilaian aktivitas siswa dan guru (Arikunto, 2010) sebagai berikut:

$$
\begin{array}{ll}
76 \%-100 \% & =\text { Baik sekali } \\
51 \%-75 \% & =\text { Baik } \\
26 \%-50 \% & =\text { Cukup } \\
<26 \% & =\text { Kurang }
\end{array}
$$

Indikator keberhasilan penelitian tindakan kelas ini mengacu pada Kriteria Ketuntasan Minimum (KKM) mata pelajaran yang ditetapkan di sekolah, yaitu nilai 75. Indikator persentase ketuntasan hasil belajar siswa dengan menggunakan media kolase secara klasikal adalah $\geq 75 \%$ siswa dengan memperoleh nilai $\geq 75$, maka penelitian ini dianggap berhasil dan selesai, sehingga tidak perlu dilakukan pembelajaran kesiklus-siklus selanjutnya. 


\section{HASIL DAN PEMBAHASAN}

Kegiatan pra siklus dilakukan pada hari selama 1 hari pada Bulan November 2020 dengan alokasi waktu 2 × 35 menit. Pembelajaran dilakukan seperti biasa peneliti tidak menggunakan media kolase. Di akhir pembelajaran siswa diberikan tes, adapun hasil belajar siswa sebelum menggunakan media kolase didapat nilai rata-rata sebesar 74,89 dengan persentase ketuntasan belajar tematik pelajaran PPKn dan SBdP diperoleh 52\% (16 siswa) dari 31 responden. Dari indikator yang peneliti tetapkan bahwa secara klasikal capaian hasil belajar siswa harus $\geq 75 \%$ dengan memperoleh nilai $\geq 75$ yang artinya ketuntasan pada pembelajaran prasiklus tersebut belum tercapai.

Pelaksanaan penelitian tindakan kelas siklus pertama dilakukan pada 11 November 2020 pukul 10:00 s.d 11:10 WIB dengan alokasi waktu 2 × 35 menit. Pembelajaran siklus pertama dilakukan dengan menggunakan media kolase. Media kolese disiapkan oleh peneliti dengan beberapa topik cerita singkat. Diakhir pembelajaran siswa diberikan tes yang sama dengan tes yang diberikan pada pra siklus. Hasil belajar tematik PPKn dan SBdP siswa kelas IV SD siklus pertama diperoleh nilai rata-rata 76,30 dengan persentase ketuntasan hasil belajar 68\% (21 siswa) dengan kriteria baik.

Selama pembelajaran menggunakan media kolase, siswa terlihat cukup antusias walaupun terlihat ada siswa yang hanya diam saja. Rata-rata dan persentase ketuntasan hasil belajar tematik PPKn dan SBdP siswa mengalami peningkatan dibandingkan dengan hasil belajar pada prasiklus di mana diperoleh nilai rata-rata 76,30 dengan persentase ketuntasan hasil belajar 68\% (21 siswa), namun hasil belajar tersebut masih belum sesuai dengan yang diharapkan akan tetapi termasuk dalam kriteria baik. Berdasarkan perolehan nilai rata-rata dan persentase ketuntasan hasil belajar PPKn dan SBdP siklus pertama yang belum maksimal, maka penelitian dilanjutkan pada siklus kedua.

Berdasarkan hasil refleksi siklus pertama dan rencana yang telah disusun, kegiatan pembelajaran siklus kedua. Pembelajaran siklus kedua dilakukan pada 18 November 2020 pukul 10:00 s.d 11:10 WIB dengan alokasi waktu $2 \times 35$ menit. Pembelajaran dilakukan dengan menggunakan media kolase yang telah disiapkan dan pada pembelajaran ini peneliti dan guru melibatkan siswa dalam membuat media kolase lainnya. Siswa bebas memilih topik dengan pedoman yang diuraikan oleh guru sesuai tema pembelajaran. Peralatan disiapkan oleh siswa dan juga guru karena pada pertemuan sebelumnya siswa sudah di instruksikan akan membuat media kolase. Di akhir pembelajaran siswa diberikan tes yang berbeda dengan yang diberikan di siklus sebelumnya.

Hasil belajar siklus kedua pada pembelajaran tematik PPKn dan SBdP diperoleh nilai rata-rata 79,00 dengan persentase ketuntasan hasil belajar 90\% (28 siswa), sehingga pembelajaran yang telah dilakukan dengan kriteria baik sekali. Hal ini setelah dilakukan pembelajaran menggunakan media kolase, siswa terlihat antusias dan mengukuti pembelajaran dengan baik dan bersemangat.

Rata-rata dan persentase ketuntasan hasil belajar tematik siswa fokus pembelajaran tematik PPKn dan SBdP mengalami peningkatan dan perubahan sikap dari setiap siklusnya dengan kategori baik. Hasil belajar tematik fokus pembelajaran PPKn dan SBdP pada pra siklus kesiklus pertama dan kedua terus mengalami peningkatan. Hasil di atas selaras dengan apa yang disampaikan oleh Susanto (2013) bahwa hasil belajar adalah perubahan-perubahan yang terjadi pada diri siswa, baik yang menyangkut aspek kognitif, afektif, dan psikomotor sebagai hasil dari kegiatan belajar. Artinya tindakan yang diberikan peneliti dan guru kelas kesiswa yaitu dengan menggunakan media kolase sangat tepat. Karena kemudahan dan manfaatnya yang dapat membuat siswa lebih tertarik dan antusias mengikuti kegiatan pembelajaran. Hal ini sesuai dengan pendapat Arsyad (2007) bahwa media pembelajaran dapat memperjelas penyajian pesan atau informasi sehingga dapat memperlancar proses dan hasil belajar. Media pembelajaran dapat meningkatkan dan mengarahkan perhatian siswa sehingga dapat menimbulkan motivasi belajar, interaksi yang lebih langsung antara siswa dan lingkungannya, dan kemungkinan siswa untuk belajar sendiri-sendiri sesuai dengan kemampuan dan minatnya.

Hasil penelitian ini juga sejalan dengan hasil penelitian (Ridya \& Mungit, 2013) hasil penelitiannya menunjukkan adanya peningkatan hasil belajar melalui penggunaan media kolase siswa kelas V SDN Pamotan 1 Porong-Sidoarjo. Siklus I persentase ketuntasan $71,25 \%$, siklus II persentase ketuntasan $82,5 \%$, dan meningkat pada siklus III dengan perolehan $92,5 \%$.

Media pembelajaran dapat mengatasi keterbatasan indera, ruang dan waktu. Dan dengan menggunakan media pembelajaran dapat memberikan kesamaan pengalaman belajar kepada siswa. Begitupun penggunaan media kolase yang memiliki sifat konkret, karena melalui gambar siswa dapat melihat jelas sesuatu, kolase memberikan pengalaman yang 
berbeda dan bervariasi, sehingga lebih merangsang minat siswa untuk belajar, menumbuhkan sikap dan keterampilan tertentu, sehingga siswa tertarik untuk menggunakan media tersebut. Salah satu kelebihan kolase adalah bahan yang digunakan bisa menyesuaikan dengan keadaaan lingkungan, misalkan jika di daerah tersebut sulit dijumpai, maka dapat diganti dengan bahan yang lain.

Berdasarkan perolehan nilai rata-rata dan persentase ketuntasan hasil belajar siswa yang mengalami peningkatan disetiap siklusnya, maka penelitian tindakan kelas ini telah mencapai target yang ditetapkan oleh peneliti sehingga penelitan dihentikan disiklus kedua. Untuk lebih jelas peneliti sajikan dalam bentuk gambar diagram batang sebagai berikut.

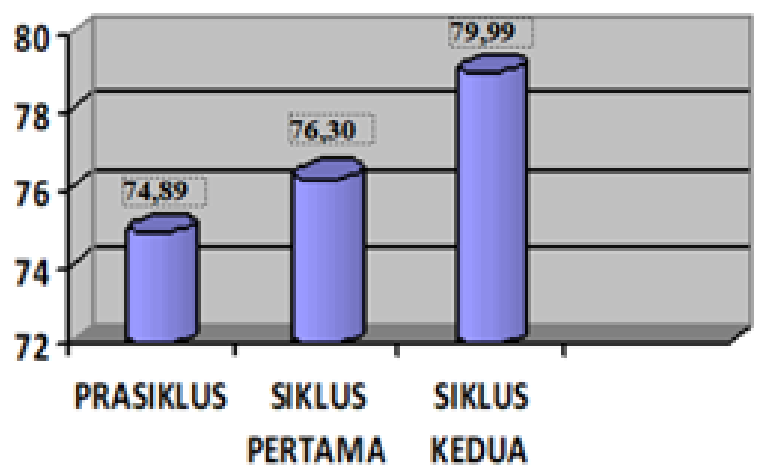

Gambar 2. Diagram Batang Rata-rata Hasil Belajar Siswa

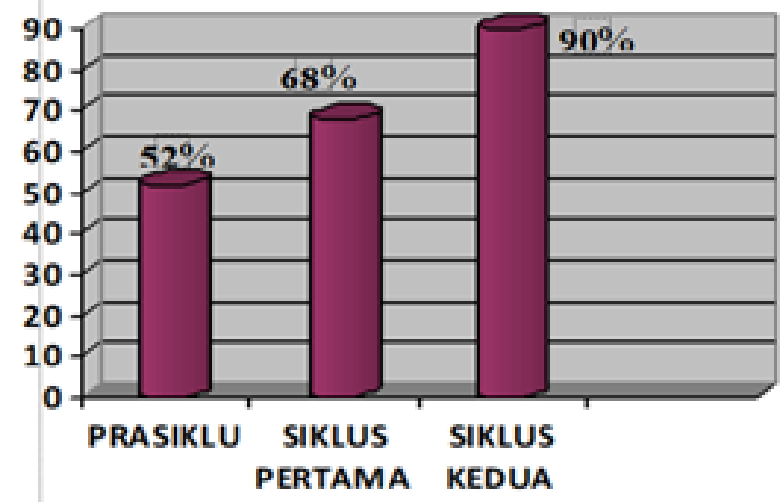

Gambar 3. Diagram Batang Persentase Ketuntasan Hasil Belajar Siswa

Adapun hasil pengamatan aktivitas belajar siswa siklus pertama dari 31 siswa terlihat $81 \%$ siswa memperhatikan instruksi/ penjelasan guru dengan kriteria baik sekali, $71 \%$ siswa antusias selama proses pembelajaran dengan kriteria baik, 68\% siswa memberikan tanggapan/respon dengan kriteria baik, dan $87 \%$ siswa aktif menggunakan media kolase dengan kriteria baik sekali. Sedangkan pada siklus kedua dari 31 siswa terlihat $97 \%$ siswa memperhatikan instruksi/penjelasan guru dengan kriteria baik sekali, 90\% siswa antusias selama proses pembelajaran dengan kriteria baik sekali, 87\% siswa memberikan tanggapan/respon dengan kriteria baik sekali, dan 94\% siswa aktif menggunakan media kolase dengan kriteria baik sekali.

Sedangkan, hasil pengamatan aktivitas mengajar guru pada siklus pertama dan siklus kedua guru melakukan apersepsi, menyampaikan tujuan dan materi pembelajaran, menjelaskan langkahlangkah menggunakan media kolase, membimbing/ mengarahkan kerja siswa, mempresentasikan hasil kerja siswa, dan melakukan kesimpulan pembelajaran dengan kriteria baik sekali. Dari tujuh aspek yang diamatai semua dilakukan dengan kriteria baik sekali.

Hasil refleksi selama pelaksanaan pembelajaran siklus pertama dan kedua, ketika siswa dapat membuat media kolase secara mandiri sesuai sub tema yang dipilih sendiri ternyata sangat efektif. Aktivitas siswa dan guru sangat terarah dan baik. Dengan menggunakan media kolase yang memiliki bersifat konkret, karena melalui gambar siswa dapat melihat jelas sesuatu, kolase memberikan pengalaman yang berbeda dan bervariasi sehingga lebih merangsang minat siswa untuk belajar, menumbuhkan sikap dan keterampilan tertentu, sehingga siswa tertarik untuk menggunakan media tersebut, karena salah satu kelebihan kolase adalah bahan yang digunakan bisa menyesuaikan dengan keadaaan lingkungan dimana siswa tinggal dan sangat mudah untuk didapatkan.

\section{PENUTUP}

\section{Kesimpulan}

Hasil belajar siswa kelas IV SD pada pembelajaran tematik mengalami peningkatan baik dari nilai rata-rata dan persentase ketuntasan hasil belajar secara klasikal setelah menggunakan media kolase. Peningkatan nilai rata-rata siswa dari 74,89 pada prasiklus meningkat menjadi 76,30 pada siklus pertama, dan menjadi 79,00 pada siklus kedua. Begitu peningkatan persentase ketuntasan hasil belajar siswa setiap siklusnya, dari $52 \%$ pada prasiklus menjadi $68 \%$ pada siklus pertama dan menjadi $90 \%$ pada siklus kedua. Hasil penelitian tindakan kelas secara klasikal telah mencapai indikator yang ditetapkan yaitu persentase ketuntasan belajar siswa mencapai lebih dari $75 \%$ siswa dengan memperoleh nilai lebih dari 75. Aktivitas belajar siswa dan juga aktivitas mengajar guru selama proses pembelajaran dengan kriteria sangat baik. 


\section{Saran}

Dari hasil temuan penelitian ini, beberapa saran yang dapat penulis sampaikan sebagai berikut: (1) untuk siswa hendaknya siswa dibiasakan dengan membuat tugas baik di sekolah maupun di rumah dengan mengaitkan pengalaman sehari-hari; (2) bagi guru, sebaiknya peran sebagai fasilitator dapat membuat siswa lebih mandiri dalam belajar, guru mampu memilih, menggunakan, dan memanfaatkan media pembelajaran karena peran media pembelajaran dapat meningkatkan hasil belajar siswa; dan (3) bagi pihak sekolah sebaiknya mewajibkan para guru dalam setiap pembelajaran dikelas menggunakan media pembelajaran, sehingga sebagai alternatif dalam upaya meningkatkan hasil belajar siswa di SD.

\section{DAFTAR PUSTAKA}

Arikunto, Suharsimi. (2010). Prosedur Penelitian Suatu Pendekatan Praktik. Jakarta: Rineka Cipta.

Arsyad, A. (2007). Media Pembelajaran. Jakarta : Raja Grafindo Persada.

Hasuki, I. (2010). Manfaat Main Kolase Untuk Anak.: Diakses melalui https://keluargasehat. wordpress.com/2010/11/30/manfaat-mainkolase-untuk-anak/ pada 2 Oktober 2020

Indarti, Titik. (2008). Penelitian Tindakan Kelas (PTK) dan Penulisan Ilmiah. Surabaya: FBS Unesa.

Lubis, M.A. (2020). Peningkatan Hasil Belajar Siswa dengan Menggunakan Media Gambar berbasis Kolase pada Pembelajaran Tematik di MI Padangsidempuan Angkola Julu. Forum Paedagogik, 8(1), 90-105. Retrieved from http:/ / jurnal.iain-padangsidimpuan.ac.id /index. php/JP/article/view/2603/2013.

Nugraheni, R.W. \& Sudianto, M. (2013). Meningkatkan Hasil Belajar IPS dengan Menggunakan Media Kolase pada Siswa Kelas V SDN Pamotan 1 Kecamatan Porong Kabupaten Sidoarjo. Jurnal Penelitian Pendidikan Guru Sekolah Dasar, 1 (2), 1-10. Retrieved from https://jurnalmahasiswa.unesa. ac.id/index.php/jurnal-penelitian-pgsd/article/ view/3148/1841

Saputro, H.B. \& Soeharto. (2015). Pengembangan Media Komik berbasis Pendidikan Karakter pada Pembelajaran Tematik-Integratif Kelas IV SD. Jurnal Prima Edukasia, 3 (1), 61-72. DOI: 10.21831/jpe.v3i1.4065.

Shalahuddin. (2019). Implementasi Media Pembelajaran Kolase berbasis Pemanfaatan Daur Ulang Sampah pada Pembelajaran Tematik untuk Meningkatkan Kreativitas MIS Nurul Yaqin Sungai Duren. (PEJ) Primary Education Journal, 1 (3), 1-14. Retrieved from http://pej.ftk.uinjambi.ac.id/index.php/PEJ/ article/view/38

Sinaga,I.S. (2020). Pemanfaatan Media Pembelajaran Berbasis TIK oleh Guru SD. Tesis Tidak Diterbitkan. Jambi: Universitas Jambi. Diakses melalui https:/ / repository.unja.ac.id/11685/

Sudrajat, A. (2008). Media Pembelajaran. Jakarta: PT. Raja Grafindo Persada.

Sunarti; Rahmati, S., \& Wardani, S. (2016). Pengembangan Game Petualangan "Si Bolang" sebagai Media Pembelajaran Tematik untuk Meningkatkan Motivasi dan Prestasi Belajar Siswa Kelas V Sekolah Dasar. Jurnal Cakrawala Pendidikan, XXXV (1), 58-68. DOI: 10.21831/ cp.v1i1.8365

Susanto, Ahmad. (2013). Teori Belajar dan Pembelajaran di Sekolah Dasar. Jakarta: Kencana Prenada Media Group.

Veronica,I.; Subekti, E.E. \& Tsalatsa, A.N. (2019). Pengembangan Media Pembelajaran Scrapbook pada Pembelajaran Tematik Kelas I SDN Tamansari 01 Pati. Jurnal Sinektik, 2 (1), 26-36. DOI: $10.33061 /$ js.v2i1.2986

Wicaksono, L \& Duta, D. (2020). Pemanfaatan Media Pembelajaran Berbasis ICT oleh Guru Penjas Kota Bandar Lampung. Jurnal Kejaora: Jurnal Kesehatan Jasmani dan Olah Raga, 5 (1), 41-49. Retrieved from http://repository.lppm.unila. ac.id/20684/

Yusrizal, Safiah, I., Nurhaidah. (2017). Kompetensi Guru dalam Memanfaatkan Media Pembelajaran Berbasis TIK di SD Negeri 16 Banda Aceh. Jurnal Ilmiah Pendidikan Guru Sekolah Dasar, 2 (2), 126134. Retrieved from http://www.jim.unsyiah. ac.id/pgsd/article/view/4573/2075 
Peningkatan Hasil Belajar...

52 PERSPEKTIF Ilmu Pendidikan - Vol. 35 No. 1 April 2021 